\title{
Pengaruh Model Pembelajaran Kooperatif Teknik Kartu Arisan Dalam Pembelajaran Matematika Siswa
}

\author{
Mesi Oktafia \\ Institut Agama Islam Negeri Kerinci, Jalan Kapten Muradi Kota Sungai Penuh, Jambi. 37112 - Indonesia \\ mesioktafia10@gmail.com
}

\begin{abstract}
This study aims to determine the student activity during the learning process using cooperative learning model of Arisan Card techniques and also to determine the average of mathematics learning result of students using cooperative learning model of Arisan Card technique. This research type was quasi-experiment with randomized control group only design model. The result of data analysis showed that the percentage of student activity using cooperative learning model of arisan card technique was better than the percentage of student activity using who do not use it. The students' mathematics learning achievements who using cooperative learning model of arisan card technique was better than the students' mathematics learning achievements who using it.
\end{abstract}

Keywords: Cooperative Learning, Arisan Cards Technique, Learning Activity, Learning Achievement

\begin{abstract}
Abstrak
Penelitian ini bertujuan untuk mengetahui aktivitas siswa selama proses pembelajaran menggunakan model pembelajaran kooperatif teknik Kartu Arisan. Selain itu juga bertujuan untuk mengetahui rata-rata hasil belajar matematika siswa menggunakan model pembelajaran kooperatif teknik Kartu Arisan. Jenis penelitian ini adalah penelitian eksperimen semu dengan model rancangan randomized control group only design. Hasil analisis data menunjukkan bahwa hasil belajar matematika siswa yang menggunakan model pembelajaran kooperatif teknik kartu arisan lebih baik dari pada hasil belajar matematika siswa yang menggunakan model pembelajaran biasa. Hasil analisis observasi menunjukkan bahwa persentase aktivitas siswa menggunakan model pembelajaran kooperatif teknik kartu arisan lebih baik dari pada persentase aktivitas siswa siswa yang menggunakan pembelajaran biasa.
\end{abstract}

Kata kunci: Model Pembelajaran Kooperatif, Teknik Kartu Arisan, Aktivitas Belajar, Hasil Belajar

Aktivitas dan hasil belajar memiliki hubungan yang sebanding dalam pembelajaran, yaitu apabila dikehendaki hasil belajar yang baik maka dibutuhkan aktivitas belajar yang lebih besar. Hal ini menempatkan aktivitas dan hasil belajar pada posisi yang terpenting di dalam proses pembelajaran. Dapat dikatakan juga bahwa pembelajaran yang menekankan aktivitas belajar akan menjadi lebih bermakna dan membawa siswa pada pengalaman belajar yang baik, mengesankan dan terlibat aktif dalam pembelajaran, sehingga siswa mampu mengembangkan bakat yang dimiliki, berpikir kritis serta dapat memecahkan masalah yang diberikan sehingga mengarah pada peningkatan hasil belajar. Idealnya aktivitas belajar perlu ditingkatkan dalam proses pembelajaran tak terkecuali dalam pembelajaran matematika.

Peningkatan aktivitas belajar memberikan dampak pada pembelajaran matematika dan peningkatan hasil belajar matematika, dimana diketahui bahwa pembelajaran matematika itu sendiri merupakan suatu kegiatan untuk memperoleh pengetahuan yang dibangun oleh siswa sendiri, sehingga siswa dituntut untuk berfikir logis, kritis, kreatif, dan sistematis. Disamping itu belajar matematika memerlukan kegiatan mental yang tinggi, karena matematika berkenaan dengan ide-ide abstrak yang terdiri dari simbol-simbol yang tersusun. Untuk memanipulasi simbol-simbol itu terlebih dahulu konsepnya harus dipelajari dan dikuasai dengan baik oleh siswa. Sejalan dengan hal tersebut terlihat bahwa belajar matematika memerlukan keteraturan mulai dari keteraturan dari konsep yang sederhana 
ke konsep yang lebih tinggi, dari hal-hal yang konkrit ke hal-hal yang abstark.

Berdasarkan hasil observasi dan wawancara yang dilakukan di SMPN 27 Padang, pada proses pembelajaran berlangsung, siswa yang pintar saja yang sering tampil untuk mengerjakan tugas atau latihan yang diberikan guru, sedangkan siswa yang lain hanya menyalin jawaban, walaupun sudah diberikan motivasi dengan memberi reward bagi setiap siswa yang tampil sekalipun jawaban yang diberikan salah. Pengalaman yang seharusnya diperoleh siswa terlewati, sehingga siswa kurang memahami materi yang diajarkan serta jarang mendapat kepuasan dalam mempelajari matematika. Pembelajaran yang umumnya masih bersifat satu arah, sehingga terjadi proses pembelajaran yang kurang bermakna. Selain itu berdasarkan hasil pengamatan peneliti, sebagian besar siswa SMPN 27 Padang beranggapan bahwa siswa yang pintar sajalah yang dapat menyelesaikan soal-soal latihan yang diberikan guru dengan benar sedangkan siswa yang lemah selalu salah dalam mengerjakannya, akibatnya siswa yang lemah selalu menunggu jawaban dari siswa yang pintar dan siswa yang lemah juga tidak mempunyai rasa tanggung jawab terhadap latihan yang diberikan oleh guru. Oleh sebab itu apabila hal tersebut terus berlanjut siswa yang pintarlah yang selalu mendomonasi proses pembelajaran.

Untuk itu perlu dilakukan usaha agar semua siswa dapat terlibat aktif dalam proses pembelajaran dan mempunyai tanggung jawab sendiri terhadap tugas yang diberikan sehingga hasil belajar matematika siswa juga akan meningkat yaitu dengan menerapkan model pembelajaran kooperatif teknik kartu arisan. Pembelajaran kooperatif adalah pembelajaran yang dilakukan dengan cara kerja kelompok. Seperti yang diungkapkan oleh Muliyardi (2003) bahwa "Pembelajaran kooperatif mencakupi kelompok kecil siswa yang bekerja sebagai sebuah tim untuk menyelesaikan sebuah masalah, menyelesaikan suatu tugas atau mengerjakan sesuatu untuk mencapai tujuan bersama“. Pembelajaran kooperatif memberikan kesempatan kepada siswa untuk memperoleh pengetahuan bukan hanya dari guru saja tetapi juga dari siswa lainnya dengan melakukan kerja sama dan saling membantu antar anggota kelompok, sehingga di dalam kelas memungkinkan terjadinya interaksi yang beragam yaitu antar guru dengan siswa dan antar sesama siswa.

Adapun unsur-unsur dasar pembelajaran kooperatif yang dikemukankan oleh Ibrahim (2000), adalah 1) Siswa dalam kelompoknya haruslah beranggapan bahwa mereka "sehidup sepenanggungan"; 2) Siswa bertanggung jawab atas segala sesuatu di dalam kelompoknya, seperti milik mereka sendiri; 3) Siswa haruslah melihat bahwa semua anggota di dalam kelompoknya memiliki tujuan yang sama; 4) Siswa haruslah membagi tugas dan tanggung jawab yang sama di antara kelompoknya; 5) Siswa akan dikenai evaluasi atau diberikan hadiah/penghargaan yang juga akan dikenakan untuk semua anggota kelompok; 6) Siswa berbagi kepemimpinan dan mereka membutuhkan keterampilan untuk belajar bersama selama proses belajarnya; dan 7) Siswa akan diminta mempertanggungjawabkan secara individual materi yang ditangani dalam kelompok kooperatif. Dari unsur-unsur tersebut dapat dikatakan bahwa pembelajaran kelompok merupakan pembelajaran yang setiap anggotanya saling membantu antara satu dengan yang lainnya. Setiap anggota kelompok dituntut untuk bisa memberikan pendapat, ide dan pemecahan masalah sehingga dapat tercapai tujuan belajar. 
Model kartu arisan menggunakan prinsip arisan yaitu mendapatkan giliran mencari pertanyaan dari jawaban sesuai undian. Jawaban dan pertanyaan dibuat berpasangan. Seluruh kartu jawaban dibagikan kepada seluruh peserta didik sedangkan kartu pertanyaan dipegang oleh guru. Ketika guru membacakan setiap kartu soal peserta didik yang mendapat kartu jawaban yang sesuai dengan kartu soal yang dibacakan harus menunjukan (Ernayetti, 2018). Jadi Teknik kartu arisan adalah suatu model pembelajaran yang memberikan kesempatan kepada siswa untuk terlibat aktif dalam proses pembelajaran dengan cara mencari jawaban dari setiap pertanyaan dari kartu soal yang dipegang oleh oleh guru (Malalina, 2018). Hasil penelitian sebelumnya menunjukkan bahwa model pembelajaran ini dapat meningkatkan prestasi belajar (Abidin, 2017), motivasi dan hasil belajar siswa (Megantorowati, 2012).

Adapun langkah-langkah model pembelajaran kooperatif teknik kartu arisan adalah 1) Guru mengelompokkan siswa menurut tingkat kemampuannya; 2) Guru menjelaskan materi dengan mengikutsertakan siswa dalam menemukan suatu konsep dan memberikan kesempatan kepada siswa untuk memberikan ide dalam menyelesaikan suatu persoalan; 3) Guru memberikan kartu soal yang telah berisi satu buah soal yang berbeda untuk setiap siswa, dan meminta siswa untuk menyelesaikannya secara individu dengan batas waktu yang telah ditentukan; 4) Setelah semua siswa menyelesaikan soal yang ada pada kartu soal, maka guru memberikan kesempatan kepada siswa untuk mendiskusikan setiap jawaban dengan anggota kelompok masing-masing; 5) Setiap siswa di dalam kelompok saling bertukar pendapat dan ide mereka; 6) Semua siswa mengumpulkan kartu soalnya agar diundi oleh guru dengan cara mengambil secara acak salah satu kartu soal, kemudian diberikan agar dipresentasikan oleh siswa yang memiliki kartu soal tersebut; dan 7) Apabila jawaban benar maka akan diberikan penghargaan pada kelompok di akhir pembelajaran (Almash, 2014). Adapun tujuan penelitian ini adalah untuk mengetahui aktivitas siswa selama proses pembelajaran menggunakan model pembelajaran kooperatif teknik kartu arisan, serta untuk mengetahui rata-rata hasil belajar matematika siswa menggunakan model pembelajaran kooperatif teknik kartu arisan.

\section{METODE}

Penelitian ini dilaksanakan dengan menggunakan metode Quasi Experiment (eksperimen semu) dengan pendekatan kuantitatif. Penelitian ini menggunakan dua kelas yaitu kelas eksperimen dan kelas kontrol. Variabel dalam penelitian ini terdiri dari variabel bebas yaitu penerapan model pembelajaran kooperatif teknik kartu arisan dan pembelajaran konvensional, variabel terikat yaitu hasil belajar dan aktivitas siswa. Desain yang digunakan untuk melihat pengaruh penerapan model pembelajaran kooperatif teknik kartu arisan adalah desain Randomized Control Group Only Design (Suryabrata, 2008). Populasi dalam penelitian ini adalah seluruh siswa kelas VIII SMP N 27 Padang. Untuk menentukan sampel pada penelitian ini digunakan teknik random sampling. Untuk mengumpulkan data digunakan beberapa instrument penelitian, yaitu lembar observasi dan test akhir. 


\section{Teknik Analisis Data}

\section{Aktivitas Belajar Siswa}

Data aktivitas siswa selama berinteraksi antar sesamanya yang ada pada lembar observasi disajikan dalam persentase, dengan menggunakan rumus $\mathrm{P}=\mathrm{x} 100 \%$ (Sudjana, 2005). Kriteria penilaian keaktifan siswa menurut Dimyati dan Mudjiono (2006) adalah 0\% $\leq \mathrm{P}<25 \%$ (sedikit sekali), $25 \% \leq \mathrm{P}<50 \%$ (sedikit), $50 \% \leq \mathrm{P}<75 \%$ (banyak) dan $75 \% \leq \mathrm{P} \leq 100 \%$ (banyak sekali).

\section{Hasil Belajar Siswa}

Untuk menganalisis data hasil penelitian digunakan uji hipotesis yaitu dengan uji perbedaan dua rata-rata atau uji-t seperti yang dikemukakan oleh Sudjana (2005). Sebelum melakukan uji-t terlebih dahulu dilakukan uji normalitas dan uji homogenitas yaitu a) Uji normalitas menggunakan Chi-kuadrat. Hasil pengujian diperoleh P-value kelas eksperimen $=0,180$. P-value kelas kontrol $=0,052$. Karena pencaran titik-titik mendekati garis lurus dan P-value $>\alpha=0,05$, maka dapat disimpulkan bahwa sampel berdistribusi normal. b) Uji homogenitas variansi digunakan uji F. Hasil pengujian diperoleh P-value = 0,924, maka dapat disimpulkan sampel memiliki variansi yang homogen.

Setelah dianalisis diperoleh sampel berdistribusi normal dan homogen, maka untuk pengujian hipotesis digunakan uji t. Kriteria pengujian adalah tolak $\mathrm{H} 0$ jika $\mathrm{p}$-value $<\alpha=0,05$, dalam keadaan lainnya terima H0. Dari hasil pengujian diperoleh p-value $=0,012$, karena $p$-value $<\alpha$ maka tolak H0. Dengan demikian, hasil belajar matematika siswa kelas VIII SMPN 27 dengan pembelajaran kooperatif teknik kartu arisan lebih baik dari pada siswa dengan pembelajaran konvensional.

\section{HASIL}

\section{Hasil Observasi Aktivitas Belajar}

Data aktivitas siswa diperoleh melalui lembar observasi. Pengamatan dilakukan dengan mencatat dan mendaftar banyaknya siswa yang melakukan aktivitas sesuai dengan yang terdapat pada lembar observasi. Siswa dibagi dalam 9 kelompok, 8 kelompok terdiri dari 5 orang dan 1 kelompok terdiri dari 4 orang. Data hasil observasi mengenai kegiatan siswa dalam pembelajaran dapat dilihat pada Tabel 1.

\section{Tabel 1}

Data hasil observasi aktivitas siswa

\begin{tabular}{|c|c|c|c|c|c|c|c|c|}
\hline \multirow{2}{*}{ No } & \multirow{2}{*}{ Aktivitas Siswa } & \multicolumn{6}{|c|}{ Presentase aktivitas siswa pada pertemuan } & \multirow{2}{*}{$\begin{array}{c}\text { Rata- } \\
\text { rata } \\
(\%)\end{array}$} \\
\hline & & 1 & 2 & 3 & 4 & 5 & 6 & \\
\hline 1 & $\begin{array}{l}\text { Mengajukan } \\
\text { pertanyaan kepada } \\
\text { guru/teman }\end{array}$ & 25 & 25 & 27,27 & 29,55 & 36,36 & 40,91 & 30,68 \\
\hline 2 & $\begin{array}{l}\text { Mengerjakan soal } \\
\text { pada kartu soal }\end{array}$ & 90,91 & 93,18 & 95,45 & 95,45 & 100 & 100 & 95,83 \\
\hline 3 & $\begin{array}{l}\text { Menjawab pertanyaan } \\
\text { guru/teman }\end{array}$ & 13,64 & 18,18 & 13,64 & 20,45 & 22,73 & 27,27 & 19,32 \\
\hline
\end{tabular}




\begin{tabular}{|c|l|c|c|c|c|c|c|c|}
\hline 4 & $\begin{array}{l}\text { Berdiskusi didalam } \\
\text { kelompok untuk } \\
\text { memecahkan masalah }\end{array}$ & 70,45 & 75 & 79,55 & 79,55 & 84,09 & 95,45 & 80,68 \\
\hline 5 & Menyalin catatan & 81,82 & 88,64 & 95,45 & 97,73 & 100 & 100 & 93,94 \\
\hline 6 & $\begin{array}{l}\text { Menyimpulkan materi } \\
\text { pelajaran }\end{array}$ & 15,91 & 18,18 & 22,72 & 25 & 18,18 & 29,55 & 21,59 \\
\hline
\end{tabular}

Pada Tabel 1 terlihat bahwa aktivitas belajar siswa dengan model pembelajaran kooperatif teknik kartu arisan cenderung meningkat setiap pertemuannya.

\section{Mengajukan Pertanyaan kepada Guru/Teman}

Aktivitas mengajukan pertanyaan dalam proses pembelajaran mengalami peningkatan yang signifikan. Hal ini terlihat pada awalnya hanya beberapa siswa yang mau mengajukan pertanyaan dari guru/teman karena merasa malu, takut ditertawakan oleh temannya, dan takut salah dalam bertanya. Siswa belum terbiasa dan tidak mempunyai kemauan untuk memberikan pertanyaan kepada guru/temannya, namun setelah beberapa pertemuan siswa mulai tidak takut dan malu lagi untuk bertanya kepada guru/teman karena dengan memberikan pertanyaan mereka akan lebih memahami materi yang tidak dimengerti.

Tingkat persentase aktivitas mengajukan pertanyaan kepada guru/teman tergolong pada kategori sedikit dikarenakan sebagian siswa yang tidak mengajukan pertanyaan kepada guru/teman telah memahami materi yang dipelajari, dan ada beberapa siswa yang pertanyaannya sama dengan pertanyaan yang telah diajukan oleh temannya. Akan tetapi ada juga siswa yang belum mengerti dengan materi yang dipelajari tetapi tidak ingin bertanya dan tidak tau apa yang ingin ditanyakan kepada guru/temannya

\section{Mengerjakan Soal pada Kartu Soal}

Aktivitas mengerjakan soal pada kartu soal cendrung mengalami peningkatan. Hal ini terlihat sebelum diterapkannya model pembelajaran kooperatif teknik kartu arisan, siswa merasa tidak percaya diri dan tidak bertanggung jawab dalam menyelesaikan latihan/tugas yang diberikan guru, merasa selalu salah dalam mengerjakannya dan sebagian besar siswa menunggu jawaban dari temannya. Namun setelah diterapkanya model pembelajarn kooperatif teknik kartu arisan setiap siswa akan merasa tertantang untuk menyelesaikan masalah yang diberikan oleh guru berupa menjawab soal yang ada pada kartu soal, yang mana masing-masing siswa mendapatkan soal yang berbeda dengan yang lainnya, sehingga mengurangi aktivitas siswa untuk menunggu jawaban dari temannya karena setiap siswa sibuk mengerjakan soalnya masing-masing. Walaupun pada beberapa pertemuan ada siswa yang tidak mengerjakan soal, hal ini dikarenakan siswa tersebut belum memahami materi pelajaran dengan baik dan merasa bingung dengan soal yang diberikan sehingga siswa tersebut tidak dapat menyelesaikan soalnya.

\section{Menjawab Pertanyaan Guru/Teman}

Aktivitas menjawab pertanyaan guru/teman dalam proses pembelajaran cendrung mengalami peningkatan. Hal ini terlihat pada awalnya hanya beberapa siswa yang mau menjawab pertanyaan dari 
guru/teman karena merasa malu, takut ditertawakan oleh temannya, dan takut salah dalam menjawab pertanyaan, namun setelah beberapa pertemuan siswa mulai tidak takut dan tidak malu lagi untuk menjawab pertanyaan guru/teman.

Tingkat persentase aktivitas ini tergolong sedikit dikarenakan pada proses pembelajaran pada saat guru/teman memberikan pertanyaan tentang materi yang dipelajari hanya beberapa orang saja yang berani menjawabnya di depan kelas walaupun ada sebagian siswa yang bisa menjawabnya tetapi tidak mau untuk menjawabnya di depan kelas.

\section{Berdiskusi dalam Kelompok untuk Memecahkan Masalah}

Aktivitas berdiskusi di dalam kelompok memiliki persentase yang cukup tinggi karena setiap siswa dituntut untuk berdiskusi dan mengeluarkan idenya dalam mengatasi masalah yang ada pada anggota kelompoknya yaitu bersama-sama dalam mengoreksi jawaban dari kartu soal pada masingmasing anggota kelompoknya dan memperbaiki jika ada jawaban yang dianggap keliru. Selain itu aktivitas ini juga tergantung kepada tingkat pemahaman materi oleh siswa

\section{Menyalin Catatan}

Pada aktivitas menyalin catatan selalu mengalami peningkatan pada setiap pertemuannya. Walaupun pada pertemuan pertama sampai pertemuan keempat masih ada siswa yang tidak melaksanakannya dengan baik, itu dikarenakan siswa tersebut merasa bahwa mencatat adalah suatu hal yang tidak penting. Akan tetapi pada pertemuan selanjutnya semua siswa telah melakukan aktivitas ini, dikarenakan setiap akhir pembelajaran guru mengingatkan untuk mengumpulkan catatan mereka.

\section{Menyimpulkan Materi Pelajaran}

Aktivitas menyimpulkan materi pelajaran pada setiap pertemuannya mengalami peningkatan, walaupun pada pertemuan kelima mengalami penurunan disebabkan karena siswa merasa sulit dalam memahami materi yang diberikan yaitu faktorisasi bentuk $x^{2}+2 x y+y^{2}$ dan $x^{2}-2 x y+y^{2}$. Tingkat persentase aktivitas ini tergolong sedikit karena sebagian siswa yang tidak ikut menyimpulkan materi pelajaran. Ada yang tidak berani untuk menyimpulkannya didepan kelas, karena takut salah dan takut ditertawakan oleh temannya, mereka malah sibuk menyimpul materi pelajaran secara sendiri-sendiri dibangkunya masing-masing, dan ada juga siswa yang menulisakannya dibuku catatan mereka.

Berdasarkan uraian di atas, dapat disimpulkan bahwa aktivitas belajar siswa di kelas VIII.6 SMP N 27 Padang dengan diterapkan model pembelajaran kooperatif teknik kartu arisan cenderung meningkat setiap pertemuannya. Walaupun pada aktivitas menyalin catatan dan menjawab pertanyaan guru dan teman tergolong sedikit dikarenakan pada aktivitas menyalin catatan sebagian siswa yang tidak mengajukan pertanyaan kepada guru/teman telah memahami materi yang dipelajari dan ada beberapa siswa yang pertanyaannya sama dengan pertanyaan yang telah diajukan oleh temannya. Akan tetapi ada juga siswa yang belum mengerti dengan materi yang dipelajari tetapi tidak ingin bertanya dan tidak tau apa yang ingin ditanyakan kepada guru/temannya. Pada aktivitas menjawab pertanyaan guru dan teman dikarenakan pada proses pembelajaran pada saat guru/teman memberikan pertanyaan tentang 
materi yang dipelajari hanya beberapa orang saja yang berani menjawabnya di depan kelas walaupun ada sebagian siswa yang bisa menjawabnya tetapi tidak mau untuk menjawabnya di depan kelas.

\section{Hasil Belajar}

Saat tes hasil belajar dilaksanakan, pada kelas eksperimen diikuti oleh 44 orang siswa dan kelas kontrol diikuti oleh 43 orang siswa. Data hasil belajar matematika siswa dapat dilihat pada lampiran. Dari hasil belajar tersebut dilakukan perhitungan rata-rata dan simpangan baku. Hasil analisis tes hasil belajar dapat dilihat pada Tabel 2 .

Tabel 2.

Hasil analisis data tes hasil belajar

\begin{tabular}{|c|c|c|c|c|c|}
\hline Kelas & $\mathbf{N}$ & $\bar{x}$ & $\mathbf{S}$ & $X_{\max }$ & $X_{\text {min }}$ \\
\hline Eksperimen & 44 & 64,53 & 20,61 & 95 & 30 \\
\hline Kontrol & 42 & 54,27 & 20,30 & 85 & 15 \\
\hline
\end{tabular}

Berdasarkan deskripsi data dan analisis data terhadap aktivitas belajar dan hasil belajar matematika siswa pada pokok bahasan Faktorisasi Suku Aljabar dengan diterapkannya model pembelajaran kooperatif teknik kartu arisan akan dibahas sebagai berikut:

Tes akhir diberikan setelah siswa selesai mempelajari pokok bahasan faktorisasi bentuk $a x^{2}+$ $b x+c$ dengan $a=1$ dan faktorisasi bentuk $a x^{2}+b x+c$ dengan $a \neq 1$. Berdasarkan tes akhir pada deskripsi dan analisis data terlihat bahwa rata-rata nilai tes akhir pada kelas eksperimen adalah 64,53 dan rata-rata nilai tes akhir pada kelas kontrol adalah 54,27. Pada kelas eksperimen nilai tertinggi adalah 95 dan nilai terendah adalah 30. Sedangkan pada kelas kontrol nilai tertinggi adalah 85 dan nilai terendah adalah 15 .

Nilai akhir kelas eksperimen lebih baik daripada kelas kontrol karena pada kelas eksperimen diberikan perlakuan model pembelajaran teknik kartu arisan yang mana masing-masing siswa dituntut untuk bertanggungjawab terhadap tugas yang diberikan, tidak menunggu jawaban dari teman lain dan berfikir sendiri-sendiri walaupun setelah itu diberikan waktu untuk berdiskusi dengan teman satu kelompok.

\section{KESIMPULAN}

Berdasarkan hasil penelitian dapat disimpulkan bahwa aktvitas belajar siswa yang menggunakan model pembelajaran kooperatif teknik kartu arisan di SMPN 27 Padang cukup baik. Hal tersebut dapat dilihat dari persentase aktivitas siswa. Persentase aktivitas siswa selama pembelajaran menunjukkan peningkatan di setiap pertemuannya. Walaupun masih ada aktivitas yang mengalami penurunan yaitu aktivitas siswa dalam menjawab pertanyaan guru/teman terdapat penurunan yaitu pada pertemuan ketiga dan aktivitas menyimpulkan materi pelajaran juga terdapat penurunan pada pertemuan kelima. Tetapi, pada umumnya semua aktivitas siswa dapat dikatakan cukup baik. Selain itu, 
rata-rata hasil belajar matematika siswa yang menggunakan model pembelajaran kooperatif teknik kartu arisan lebih baik dari pada rata-rata hasil belajar matematika siswa yang menggunakan pembelajaran konvensional.

Berdasarkan kesimpulan yang diperoleh dari hasil penelitian maka guru diharapkan dapat menerapkan model pembelajaran kooperatif teknik kartu arisan dalam pembelajaran matematika untuk meningkatkan aktivitas dan hasil matematika siswa.

\section{DAFTAR PUSTAKA}

Abidin, Z. (2017). Pengaruh Model Pembelajaran Kooperatif Tipe Kartu Arisan terhadap Prestasi Belajar Mata Pelajaran Sejarah Siswa Kelas XI SMAN 1 Seulimeum. Jurnal Ilmiah Mahasiswa Jurusan Pendidikan Sejarah, 2(2).

Almash, L. (2014). Penerapan Model Pembelajaran Kooperatif Teknik Kartu Arisan dalam Pembelajaran Matematika di kelas VIII SMP N 2 Lubuk Alung Kabupaten Padang Pariaman. Skripsi, tidak dipublikasikan. Padang: Universitas Bung Hatta.

Dimyati dan Mudjiono. (2006). Belajar dan Pembelajaran. Jakarta : Rineka Cipta.

Ernayetti, E. (2018). Penerapan Model Pembelajaran Kartu Arisan dapat Meningkatkan Hasil Belajar Peserta Didik pada Pokok Bahasan Program Linier di Kelas XI MIA 2 SMA Negeri 2 Pekanbaru. PEKA, 6(1), 58-64.

Ibrahim, M. (2000). Pembelajaran Kooperatif. Surabaya : Universitas Press

Malalina, M. (2018, February). Model Kooperatif Tipe Kartu Arisan dalam Materi Belah Ketupat dan Layang-Layang. In Prosiding Seminar Nasional Pendidikan Matematika Etnomatnesia.

Megantorowati, P. T. (2012). Penerapan Model Pembelajaran Kooperatif Teknik Kartu Arisan dalam Meningkatkan Motivasi dan Hasil Belajar Siswa. MATHEdunesa, 1(1).

Muliyardi. (2003). Strategi Belajar Mengajar Matematika. Padang: FMIPA UNP

Sudjana, N. (2005). Penilaian Hasil Proses Belajar Mengajar. Bandung : PT Remaja Rosda Karya. Suryabrata, S. (2008). Metodologi Penelitian. Jakarta : PT Raja Grafindo Persada. 